\title{
Analysis on utilization of sponge city in architectural planning and design
}

(China Construction Third Engineering Bureau Co.,Ltd Architectural Design Institute Hubei Wuhan 430000)

\section{Introduction of the sponge city}

The core of the sponge city is that the city has a very good "elasticity" in dealing with a series of related natural disasters brought about by environmental, rain and other changes and can also be called "Water Elastic City". It's like a sponge that can absorb water, so it is called the sponge city. In the context of the sponge city, the city's seepage, water absorption, purification and water storage in the rainfall process are given great emphasis on. In the process of urbanization, building is an extremely important composition, therefore, we must make effective use of the theory of sponge city in the urban building development, especially when designing buildings, we should strengthen the design of a series of parts, including building roof and paving. In addition, we should combine the design with the actual situation of urban construction and optimize rainwater collection system, so as to prepare for realizing the the sponge city better.

\section{Feasibility of the sponge} city
The core of the construction of sponge city lies in: Take the whole system of city construction as the starting point, and make scientific and reasonable planning for the urban Green Line and Blue line. In the process of developing and protecting the boundary area, natural ecosystems such as lakes, forests, wetlands and rivers should be protected at maximum. Plan and design reasonable urban development goals, and maintain the previous relevant systems. Pay attention to relevant hydrological characteristics before development. Combine the natural disasters and environmental changes effectively and expand the urban areas properly. The construction of the sponge city makes the city "resilient" to natural disasters and environmental changes, and there are three key characteristics. Firstly, the original water ecosystem can be effectively protected, and secondly, the damaged aquatic ecosystems can be restored; for the damaged water wetlands, urban green space, etc., ensure that the ecological function and hydrological system can be effectively restored by the effective application of ecological, biological and
Abstract: At this present stage, the national economy is developing rapidly, the level of productivity is constantly upgrading, and the pace of urbanization is accelerating, but inevitably, there are many problems in the process of urban construction, such as serious shortage of water resources, rainwater runoff pollution, underground drainage system and unreasonable urban construction planning, so the proposal of sponge city has solved these problems effectively. The core of the sponge city is to save water resources by reducing the demand of water resources in the traditional urbanization process, and improve the whole quality of the existing water resources, balancing the whole city ecological system. Based on this, this paper analyzes and explores the use of sponge city in architectural planning and design in detail.

Key words: the sponge city; architectural planning and design; use

Published on 30th Sept,2017 
physical methods and means, and make the overall spatial order of urban ecology, improve the diversity of ecosystems. Finally, low impact development can be carried out, and when the city is built, the development intensity should be controlled rationally to reduce the damage of the original water ecological environment. Besides, ensure the space of ecological land, carry out reasonable excavation to the rivers, lakes and ditches, and appropriately increase the water area.

\section{Urban planning methods under the concept of sponge city}

\subsection{Complete the master plan}

The direction of building sponge city usually includes runoff pollution control, rainwater resource utilization, total runoff control and so on. In each part, we should carefully analyze and master the hydrogeological characteristics and existing problems of water resources, and target one or more of them as the basic direction of the sponge city, and then determine the related indicators and targets of low-impact development control. At the same time, analyze a series of requirements and use of the overall layout and determine the key areas of low-impact development facilities.

\subsection{Special planning}

\subsubsection{Water supply system planning}

Water supply system includes drainage, water supply, water saving and water conservation, so further optimization and planning of multiple waterlogging prevention can make the city have a "sponge" function.

\subsubsection{Road system planning}

Reasonably set and design the pavement layout and greenbelts, as well as related pedestrians, driveways and parking lots, effectively exert the actual functions of road, and construct sponge city in urban road system.

\subsubsection{Green space system planning}

Park, grassland and other areas are the basic foundation of green space system which can meet people's demands for facilities like leisure and entertainment. Guarantee the basic function effectively. Meanwhile, it contains organic water supply system and has practical effects, such as water purification, drainage and so on.

\subsection{Strengthen detailed planning}

In addition to the above planning, we should also strengthen the detailed planning of the system and refine and decompose the planning reasonably. In the course of its construction, according to the different characteristics of each city, carry out detailed treatment and control the relevant planning layout, standards, progress and so on, to ensure the feasibility of implementation. At the same time, the comprehensive benefit should be analyzed to avoid the adverse effects of the construction of sponge city on the overall environment and urban development, so as to ensure the scientific validity of its application.

\section{Analysis on utilization of sponge city in architectural planning and design}

\subsection{Inventory of natural resources}

The protection of the original aquatic ecosystem is the key condition of the construction of the sponge city, so the relevant departments should strengthen the protection of the ecological sensitive areas, the undisturbed natural belts and the related vegetation. On the other hand, protect the natural drainage function during the development and construction of the project by effectively using the " design with the terrain", to minimizing hydro-geological changes in design.

\subsection{Water system and wetland planning}

In the ecological balance, climate control and urban environmental protection, urban wetland water purifier plays a very important role. Firstly, plan the construction areas that can be constructed reasonably, and adhere to relevant enforcement tools in the setting of green Line and blue line, so that this series of natural sponges can maintain the sponge throughput and flood capacity. Secondly, restore the natural ecology effectively, and in the process of restoring the green ecosystem, a series of waterworks cultivation, masonry shores and sediment eco-dredging should be carried out. It is worth emphasizing that in the process of construction, we must strengthen the management, give full play to the whole effect of artificial wetland water and natural wetland waters, rationally plan the sponge city, reduce the incidence of natural disasters such as floods and droughts, guarantee the ecological environment and promote urban development. Thirdly, we should strengthen the construction of ecological corridor and national corridor, optimize and improve a series of links in the ecosystem, develop the actual function of canal and river, and promote the good construction of ecological system.

\subsection{Urban roads}

Pay attention to improve the sewer system, firmly cement the safety cover, make full use of permeable materials to build urban road traffic, reduce droughts and flood disasters, realizing the construction of sponge city.

4.5 Application of building roof design 
The roofs of buildings have been weathered over a long period of time, so cracks are often caused due to overheating, and the problem of roof water often occurs when there is too much rainfall, affecting the service life of buildings to a certain extent. In addition, when the roof is leaking, residents' life can be affected adversely, so the design of the building roof is very important and it is also the core step to influence the construction life. Under the concept of "sponge city", paying more attention to rainwater collection and greening design in building roof design has many advantages: it not only can prevent roof temperature from rising in high temperature weather, but also can collect rainwater in time, prevent roof from accumulating water, and recycle rainwater.
To sum up, the construction of sponge city is not only a reflection of the city's focus on the establishment of low-impact development thought, but also a promotion of urban drainage and utilization. Therefore, in the process of construction and development of sponge city, we should base on the concept of sustainable development and ecological civilization construction in our country, take low-impact development as the basis of planning and design, control the target security of water resources, water ecology and water environment, so as to promote the transformation of urban development thought, realize the economical and effective use of rain, and create a healthy development road for sponge city construction with Chinese characteristics.

\section{References}

[1] Meng Lingchao. Study on the Reconstruction of Urban Ecological Landscape Based on the Concept of "Sponge City" [D]. Henan University, 2015.

[2] Dong Yuliang, Wang Xianping. Construction of Sponge City--Research and Application of Low-impact Development in Jiaxing [J]. Construction Science and Technology, 2015,07:56-57.

[3] Qian Haijiang. Analysis of Urban Green Building Planning and Design Method [J]. Sichuan Building Materials, 2015, 03:64+ 67 .

sity of Technology, 2015 